\title{
Mapping of Traffic-Related Air Pollution Using GIS Techniques in Ijebu-Ode, Nigeria
}

\author{
Oludare Hakeem Adedeji, Olasumbo Oluwafunmilayo and Tope-Ajayi Opeyemi \\ Oluwaseun
}

Received: 0109 2015 / Accepted: 1002 2015 / Published online: 30062016

(c) 2016 Faculty of Geography UGM and The Indonesian Geographers Association

\begin{abstract}
Spatial and temporal characteristics of traffic related air pollutants (CO, $\mathrm{NO}, \mathrm{NO}_{2}$ and $\left.\mathrm{SO}_{2}\right)$ in Ijebu-ode, Nigeria were determined using replicate portable gas detectors (Land Duo Multi Gas Monitor) at selected road junctions, motor garages and markets. Mapping of different concentration of air pollutants was carried out using kriging type of interpolation method in GIS environment. Concentration of CO ranges from $4.8 \mathrm{ppm}$ at Erinlu/Molipa Roundabout to 137ppm on Sagamu/Ore Expressway. Concentrations of $\mathrm{NO}_{2}$ range from 100-662 ppb with overall average value (OAV) of $299.8 \mathrm{ppb}$, while concentration of nitrogen oxide (NO) ranges between 67-302 ppb and OAV of $166.23 \mathrm{ppb}$. $\mathrm{SO}_{2}$ had concentration ranging between 38-245 ppb and an OAV of $139.07 \mathrm{ppb}$ all of which are above standard ambient air quality standards. AQI indicated very unhealthy air quality in most areas which calls for the need to establish and strengthen the health-based standard for air pollutants.
\end{abstract}

Keywords: Air pollution, Air quality index (AQI), Interpolation, Traffic emission, Ijebu-ode

\begin{abstract}
Abstrak Karakteristik spasial dan temporal polutan udara terkait lalu lintas (CO, $\mathrm{NO}, \mathrm{NO}_{2}$ dan $\mathrm{SO}_{2}$ ) di Ijebu-ode, Nigeria ditentukan dengan detektor gas portable replika (Land Duo Multi Gas Monitor) di persimpangan jalan yang dipilih, garasi bermotor dan pasar. Pemetaan berbagai konsentrasi polutan udara dilakukan dengan menggunakan jenis kriging dari metode interpolasi di GIS. Konsentrasi CO berkisar dari 4,8 ppm di bundaran Erinlu / Molipa hingga 137ppm pada Sagamu / Ore expressway. Konsentrasi $\mathrm{NO}_{2}$ berkisar antara 100-662 ppb dengan nilai rata-rata keseluruhan (OAV) 299,8 ppb, sedangkan konsentrasi nitrogen oksida (NO) berkisar antara 67-302 ppb dan OAV 166,23 ppb. $\mathrm{SO}_{2}$ memiliki konsentrasi berkisar antara 38-245 ppb dan OAV 139,07 ppb yang semua berada di atas standar kualitas udara standar ambien. AQI mengindikasikan kualitas udara yang sangat tidak sehat di sebagian besar wilayah yang menyerukan perlunya membangun dan memperkuat standar berbasis kesehatan bagi polusi udara.
\end{abstract}

Kata kunci: Polusi udara, Index kualitas udara, Interpolasi, Emisi lalu lintas, Ijebu-ode

\section{Introduction}

Air pollution is any atmospheric condition in which certain substances present in such concentrations and duration that they may produce harmful effects on man and his environment [World Bank, 2003; Cohen et al., 2004; Brezzi and Sanchez-Serra; 2014]. Presently greater percentage of the world's population lives within urban areas [Satterthwaite, 2007; Odindi et al., 2012], and urban populations and coupled with growing levels of motorization that have inevitably led to air pollution related problems [Matějíček, 2005; Brezzi and SanchezSerra; 2014]. The quality of air is a very important factor in projecting or representing the status of environment and health of any region. Worldwide, air pollution has become a major environmental problem in major cities where urban-based activities and residents generate high proportion of gas emissions [Begum et al., Revi et al., 2014]. Cities such as Lagos, Ibadan, Port Harcourt

Oludare Hakeem Adedeji, Olasumbo Oluwafunmilayo, and TopeAjayi Opeyemi Oluwaseun

Department of Environmental Management and Toxicology, Federal University of Agriculture, PMB 2240, Abeokuta, Nigeria Email: adedejioh@funaab.edu.ngPerat ditis maiorro venis maxim and Ijebu-ode in Nigeria are manifesting increasing air pollution due rapid urbanization, industrialization and economic growth [Chattopadhyay et al., 2010; Laumbach and Kipen, 2012; Dons et al., 2013]. Although there are many other sources of pollution in the urban environment, current observations have shown that more than half the pollution load in our cities is due to automobile exhaust [Tang et al., 2007; Olajire et al., 2011]. Traffic related air pollution is on the increase due to growing levels of motorization and lack of proper management of urban traffic situations [Xia and Shao, 2005; Briggs, 2007; Paez et al., 2013]. Concerns about the negative effects of urban transportation are now prominent issues due to the increasing deterioration of urban air quality [Goldin, 2000]. Primary pollutant groups include oxide of nitrogen $\left(\mathrm{NO}_{\mathrm{x}}\right)$, sulphur dioxide $\left(\mathrm{SO}_{2}\right)$, carbon monoxide $(\mathrm{CO})$, particulate matter (PM), and other air pollutants which typically present together pollution that vary by location, source activity, season, weather and year [Ozcan, 2012]. Studies have revealed air pollution as one of the major contributors to health and environmental problems including global warming, ozone layer depletion, trans-boundary smoke 
transportation, and acid rain [Cohen et al., 2004; Cohen et al., 2005; Dyominov and Zadorozhny, 2005; Jain et al., 2008; Ramanathan and Feng, 2009]. Exposures to common air pollutants have been linked to a wide range of adverse health outcomes, including respiratory and cardiovascular diseases, asthma exacerbation, reduced lung function and premature death [Touloumi et al., 2004; Clougherty et al., 2008; Jain et al., 2008; USEPA, 2009; Gulliver and Briggs, 2011; WHO, 2011; Brezzi and Sanchez-Serra; 2014].

The ability to understand the patterns and magnitude of pollution in the urban environment is increasingly important [Smallbone, 1998; Mwenda, 2011] and many developed countries of the world have in place programmes for monitoring urban air pollution. These were done by operating a certain number of monitoring stations located in several sites [Allegrini and Costabile, 2002], which is however lacking in developing countries like Nigeria. There are no proper records or documentation in the urban atmosphere in these countries despite having the fastest growing urban populations [Rahmatizadeh et al., 2003]. This is because that the cost of establishing and implementing ordinary monitoring systems is extremely high; use of analytical instruments are timeconsuming, expensive, and can seldom be applied for real-time monitoring in the field, even though these can give a precise analysis [Hadjimitsis et al., 2012]. Urban traffic-related air pollution is becoming problematic because of continuing uncertainty about the causal agents, the likelihood of important interactive and cumulative effects from different pollutants, high levels of both spatial and temporal variability in pollutant concentrations and a dearth of monitoring data [Bellander et al., 2001; Zhu et al., 2002; Briggs, 2007; Banja et al., 2010; Enkhtur, 2013]. Against this background, there is a need for improved information on levels of traffic-related air pollution which can be used to help investigate the relationship involved as inputs to health risk assessment, to assist in establishing and monitoring air quality standards [Raju et al., 2012; Dons et al., 2013]. It has been established that the measuring urban air pollutants requires a spatiotemporal data management, which is provided by advances in geographic information systems (GIS) and earth observations [Wu, 2006; ESRI, 2007; Hadjimitsis et al., 2010; Dubey, 2014; Sameen et al., 2014]. GIS-based pollution mapping, using interpolation techniques, such as inverse distance weighting and kriging have proved efficient in the assessment of urban air pollution [van der Kassteele , 2006; ESRI, 2007; Chattopadhyay et al., 2010]. Air pollution maps are potentially powerful tools particularly for urban areas for use in epidemiological studies and in identifying the "hot-spots" in need of special investigation or monitoring [Matejicek, 2005; Ettouney et al., 2009; Banja et al., 2010; Sampson et al., 2011; Sameen et al., 2014]. Integrating spatial analysis in GIS and statistical modelling can help the researcher to expand the understanding concerning the distribution of the pollutants in some locations or areas and to understand the factors that influence the trends and significance [Rahman et al., 2015]. Estimation of small-area variations in traffic pollution are important to the exposure experience of the population and may detect health effects that would have gone unnoticed with other exposure estimates [Watmough et al., 2014]. Despite increasing urban development and anthropogenic activities, monitored data on urban air pollution are sparse in Nigeria and many developing countries [Baumbach et al., 1995;Gupta et al., 2006; Abam and Unachukwu, 2009], hence the collection of accurate and reliable data necessary for the evaluation of urban air quality is therefore very important. This study aim to collect, analyze and map the gaseous traffic related air pollutants $\left(\mathrm{CO}, \mathrm{NO}_{\mathrm{x}}, \mathrm{NO}_{2}\right.$ and $\left.\mathrm{SO}_{2}\right)$ at road junctions, intersections, and motor garages in order to facilitate the management of air pollutions in the study area.

\section{The Methods}

Ijebu-ode is the second largest city in Ogun State, southwest Nigeria with about $192 \mathrm{~km}^{2}$ of land. It is approximately located between latitudes $6^{\circ} 42^{\prime} \mathrm{N}$ and $6^{\circ} 54^{\prime} \mathrm{N}$ and longitude $3^{\circ} 55^{\prime} \mathrm{E}$ and $4^{\circ} 6^{\prime} \mathrm{E}$ (Figure 1) with an average elevation of 120 metres. The climate fall into two distinct seasons i.e. the harmattan season (November to March) and the raining season (April to October) interrupted by short August break. The rains reach its peak in the months of June and September. The mean annual rainfall is about $1590 \mathrm{~mm}$; with an average annual temperature is $27.5^{\circ} \mathrm{C}$. The city is situated about $110 \mathrm{~km}$ by road northeast of Lagos the commercial nerve centre of Nigeria and about $53 \mathrm{~km}$ southeast of Ibadan, the second largest $r$ city in Africa. It has an estimated population of 222,653 as at 2007 (NPC, 2006), comprising people from different parts of the country with and population density of 481 persons per hectare. Owing to its strategic location, the city has continued to expand with physical and social infrastructural developments. The development of the city has been rapid in the past 20 year due to influx of people, industries and schools.

\section{Air pollution sampling}

Gaseous traffic related air pollutants $\left(\mathrm{CO}, \mathrm{NO}_{\mathrm{x}}\right.$ $\mathrm{NO}_{2}$ and $\mathrm{SO}_{2}$ ) were chosen as indicators of urban traffic related air pollution in the study area. The spatial and temporal of traffic related air pollution in Ijebu-ode, Nigeria is investigated based on ambient air quality levels in wet and dry seasons. Air quality measurements took place at all selected locations within Ijebu-ode in May-July 2013 (wet season) and October-December 2013 (dry season).

The designated locations were chosen after reconnaissance survey to ascertain the characteristics and distribution of pollutant sources as well as the traffic 


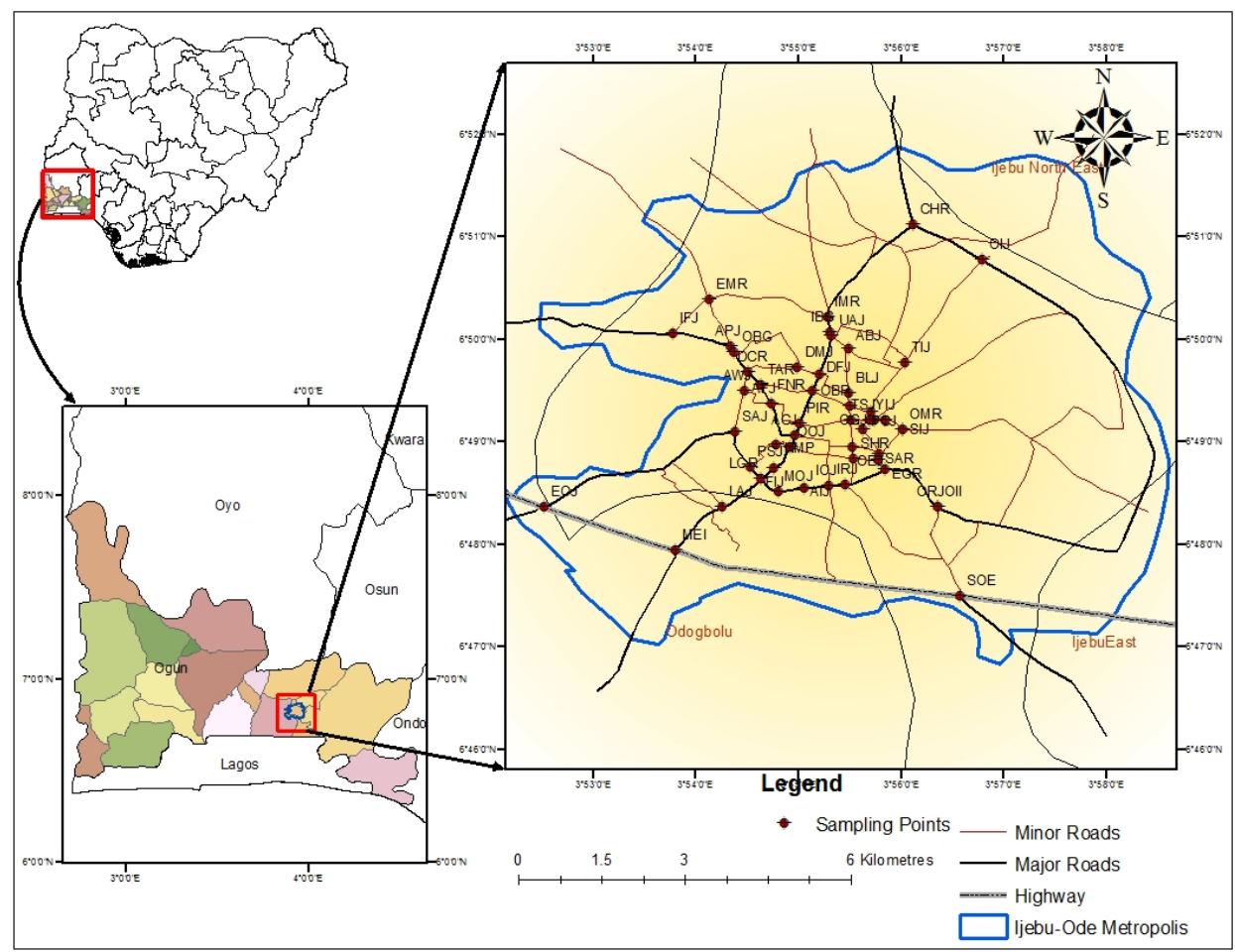

Figure 1. Map of Ijebu-ode city showing sampling locations.

volume and direction of prevailing wind [Allegrini et al, 2002].

Measurements were conducted within the city as presented in Figure 1. Air pollutants $\left(\mathrm{CO}, \mathrm{NO}_{\mathrm{x}} \mathrm{NO}_{2}\right.$ and $\mathrm{SO}_{2}$ ) measurements were carried out at selected road junctions, intersections, motor garages and markets in the study area simultaneously during the study period. The distance of the monitoring station from the major roads is about $100 \mathrm{~m}$. The measurements were taken at a height of about $1.50 \mathrm{~m}$ above ground level.

Air pollutant such as carbon monoxide (CO), carbon dioxide $\left(\mathrm{CO}_{2}\right)$, nitrous oxide $(\mathrm{NO})$, nitrogen dioxide $\left(\mathrm{NO}_{2}\right)$, and sulphur dioxide $\left(\mathrm{SO}_{2}\right)$ were determined using replicate portable gas detectors (Land Duo Multi Gas Monitor). Each gas was determined two times at $30 \mathrm{~min}$ interval for $1 \mathrm{~h}$. at all sampling sites/ stations. Background concentration checks using zero air were conducted to correct instrument drift. Highpurity air was sent into the instruments to obtain a daily true zero [Al-Awadhi, 2014].

In order to determine the traffic volume, traffic count was manually done, counting the vehicles passing on the road for 10 minute in every hour from which hourly traffic was calculated. The description of selected sites, their configuration and the traffic density are presented in table 1. Road networks and traffic data were obtained by traffic count at the monitoring sites. Meteorological parameters are taken from the meteorological station located in the city.

\section{GIS analysis for generation of maps}

Geographical Information System (GIS) is a powerful tool that facilitates linking spatial data to non-spatial information [Matejicek, 2005]. This study involved incorporating traffic related air pollution data from field measurements into digital map layers for illustrating the application of spatial analysis to Ijebu-ode area. Longitude (y-coordinate) and latitude (x-coordinate) of the sampling sites were determined using Garmin Global Positioning System (GPS) device. Air pollutant measurements and coordinates of locations were stored in excel format while the shapefile of the present extent of the ljebu-ode is imported into the GIS environment using ArcGIS 10.0 software. Attribute data were then assigned to spatial objects and the system become ready for spatio-temporal analysis and management. Mapping of areas of different concentration of air quality within the study area was carried out using kriging type of interpolation method in ArcGIS 10.0 environment.

\section{Statistical analysis}

Pearson correlation analyses were performed separately for each pollutant to ascertain relationships among the different pollutants concentration and traffic volume.

\section{Air Quality Index (AQI)}

The air quality index (AQI) which is also known as Air Pollution Index (API) [Murena, 2004] has been developed and disseminated by many agencies in US, Canada, Europe, Australia, China, Indonesia, Taiwan, etc. [Cheng et al., 2007] to convey the air quality status to the scientific community, government officials, policy maker and in particular to the general public in 
Table 1. Characteristics at A Selection of The Monitoring Sites/Street in The Study Area

\begin{tabular}{lrll}
\hline Street name & $\begin{array}{c}\text { Speed limit } \\
(\mathrm{km} / \mathrm{h})\end{array}$ & Configuration & Traffic volume (day-1) \\
\hline Alapo/Fidipote Junction & $30 \mathrm{~km} / \mathrm{h}$ & 1 lane, Residential & Medium 2000-3000 \\
Balogun Kuku/Oke Aje & $50 \mathrm{~km} / \mathrm{h}$ & 2 lanes, commercial and residential & Medium 2000-3000 \\
Junction & & & \\
Epe Garage Roundabout & $50 \mathrm{~km} / \mathrm{h}$ & 2 lanes, commercial and residential & Medium 2000-3000 \\
Erinlu/Molipa Roundabout & $50 \mathrm{~km} / \mathrm{h}$ & 2 lanes, commercial and residential & Light 1000-2000 \\
FCMB/Imepe Junction & $50 \mathrm{~km} / \mathrm{h}$ & 2 lanes, commercial and residential & Medium 2000-3000 \\
Ibadan Garage & $50 \mathrm{~km} / \mathrm{h}$ & 2 lanes, commercial and residential & Medium 2000-3000 \\
Lagos Garage Roundabout & $50 \mathrm{~km} / \mathrm{h}$ & 2 lanes, commercial and residential & Medium 2000-3000 \\
New Market Park & $50 \mathrm{~km} / \mathrm{h}$ & 2 lanes, commercial and residential & Medium 2000-3000 \\
Oke-Aje Market & $50 \mathrm{~km} / \mathrm{h}$ & 2 lanes, commercial and residential & Medium 2000-3000 \\
Oke-Owa/Ikoto./Ilese & $50 \mathrm{~km} / \mathrm{h}$ & 1 lane, commercial and residential & Medium 2000-3000 \\
Oyingbo/Olisa Juction & $50 \mathrm{~km} / \mathrm{h}$ & 2 lanes, commercial and residential & Light 1000-2000 \\
Sabo Junction & $50 \mathrm{~km} / \mathrm{h}$ & 2 lanes, commercial and residential & Medium 2000-3000 \\
Sagamu/Ore_Expressway & $80 \mathrm{~km} / \mathrm{h}$ & 2 lanes, commercial, major highway & Heavy >3000 \\
Junction & $50 \mathrm{~km} / \mathrm{h}$ & 2 lanes, commercial and residential & Medium 2000-3000 \\
Stadium/Oke Aje Junction & $30 \mathrm{~km} / \mathrm{h}$ & 1 lane, residential, schools & Medium 2000-3000 \\
Taused/Igbeba Junction & & & \\
\hline SOurce: Traflc Survey 2013. & & & \\
\hline
\end{tabular}

Source: Traffic survey 2013.

a simple and straightforward manner. The concept of air quality index (AQI) has been developed and used effectively in many industrialized countries for over last three decades. AQI is defined as an overall scheme that transforms the weighted values of individual air pollution related parameters such as sulphur dioxide $\left(\mathrm{SO}_{2}\right)$, nitrogen dioxide $\left(\mathrm{NO}_{2}\right)$ and particulate matter $<10 \mu \mathrm{m}$ (PM10), etc., into a single number or set of numbers. The AQI is a single number reporting the air quality with respect to its effects on human health [Bortnick et al., 2002; Murena, 2004]. The result is set of a rule (for example, an equation) that translates parameter values into a more parsimonious form by means of numerical manipulation. AQI is calculated by using the pollutant concentration data and the following equation [EPA, 2006].

$$
\mathrm{T}_{\mathrm{p}}=\frac{\mathrm{I}_{\mathrm{Hi}}-\mathrm{I}_{\mathrm{Lo}_{\mathrm{o}}}}{\mathrm{BP}_{\mathrm{HI}}-\mathrm{BP}_{\mathrm{Lo}}}\left(\mathrm{C}_{\mathrm{p}}-\mathrm{BP}_{\mathrm{Lo}}\right)+\mathrm{I}_{\mathrm{Lo}}
$$

where

Ip $\quad=$ the index for pollutant $\mathrm{p}$

$\mathrm{Cp} \quad=$ the rounded concentration of pollutant $\mathrm{p}$

$\mathrm{BPHi}=$ the breakpoint that is greater than or equal to $\mathrm{Cp}$

BPLo = the breakpoint that is less than or equal to $\mathrm{Cp}$

$\mathrm{BPHi}=$ the breakpoint that is greater than or equal to $\mathrm{Cp}$

$\mathrm{IHi}=$ the AQI value corresponding to $\mathrm{BPHi}$

ILo = the AQI value corresponding to BPLo

\section{Result and Discussion}

The study revealed that major parts of the city are experiencing high concentration of gaseous pollutants mainly from traffic related emission which are in excess of the maximum levels allowable under WHO guidelines. Figure 2 shows the map of the urban road network and traffic volume in the study area. The average hourly number of vehicles running on the main roads in the city ranges from 1000 to above 3000 vehicles/ day. Summary statistics of pollution concentrations within the study area are given in Table 2. A clear distinction is observed between the spatial distribution of these pollutants at locations such as the Sagamu/Ore Expressway, Oke-Aje Market and Oke-Owa/Ikoto/Ilese which have high concentration of CO: 13.7, 12.7 and $10.5 \mathrm{ppm}$ respectively compared to other areas.

Concentrations of $\mathrm{NO}_{2}$ in the study area range from $100-662 \mathrm{ppb}$ with an overall average value (OAV) of 299.8 $\mathrm{ppb}$, while concentration of nitrogen oxide (NO) ranges between 67-302 ppb an overall average value (OAV) of $166.23 \mathrm{ppb}$. Sulphur dioxide, which is a predominately anthropogenic pollutant had a concentration ranging between 38-245 ppb and an overall average value (OAV) of $139.07 \mathrm{ppb}$ (Table 2). Traffic congestion in the rush hours especially in the morning and evening periods within Ijebu-ode and along major highways surrounding the city are major contributors to the $\mathrm{CO}$, $\mathrm{NO}_{\mathrm{x}}, \mathrm{NO}_{2}$, and $\mathrm{SO}_{2}$ levels in the air. Several studies have attributed motor vehicles as the major source of nitrogen oxides $\left(\mathrm{NO}_{\mathrm{x}}\right)$ emitted to the atmosphere in most industrialized countries where road length and traffic volumes are increasing [CMRTHS, 2013; 


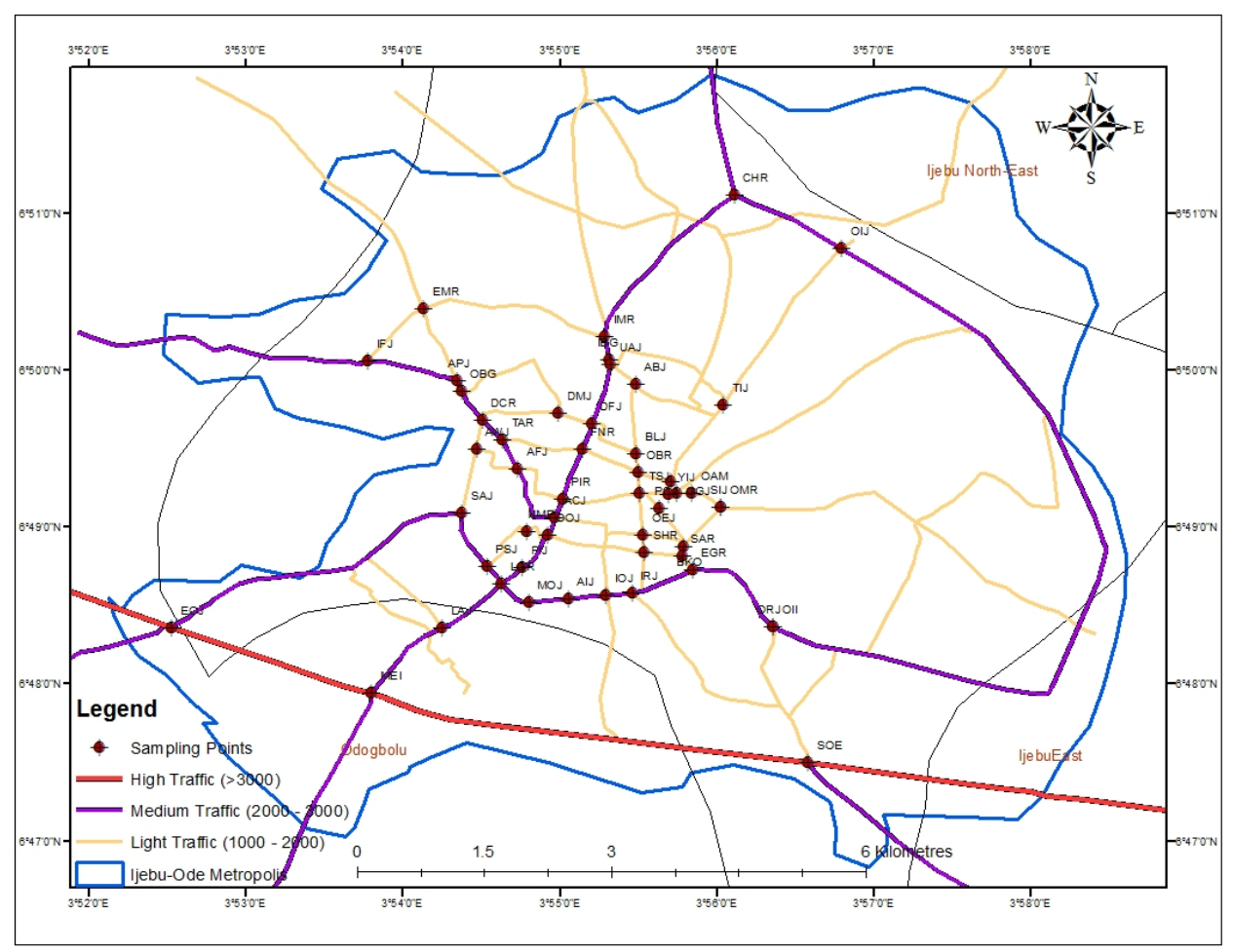

Figure 2. Map of the urban road network and traffic volume in the study area.

United Nations ESCAP, 2013]. In this study, there is high concentration of carbon monoxide $(\mathrm{CO})$ at major locations such as the Sagamu/Ore Expressway, Oke-Aje Market and Oke-owa /Ikoto/Ilese with concentrations of $13.7,12.7$ and $10.5 \mathrm{ppm}$ respectively compared to other areas. Natural background levels of carbon monoxide range between $0.009-0.0198 \mathrm{ppm}$ [WHO/ UNEP, 1992]. CO is a colorless, odorless, poisonous gas produced from burning of fuels with carbon and so the major source is road transport vehicles.

High levels of $\mathrm{CO}$ along major roads such as the Sagamu/Ore Expressway, Oke-Aje Market and Oke-owa/ Ikoto/Ilese can be attributed to heavy traffic congestion where long waiting time of vehicles at intersection was observed. Continuous exposure to higher levels for longer time periods may lead to headache, dizziness and nausea and also death [Olajire et al., 2011]. These portend a growing risk of traffic-related problems in Nigeria cities and therefore demand serious air quality measures. High concentrations of nitrogen oxides $\mathrm{NO}_{x}$ (including $\mathrm{NO}$ and $\mathrm{NO}_{2}$ ) observed in most of the sampling sites point to the level of emission from vehicles plying the roads in the study area.

$\mathrm{NO}_{x}$ concentrations exceeded the existing secondary standards of $0.053 \mathrm{ppm}$ (parts per million) averaged over a year for $\mathrm{NO}_{2}$ and while the concentrations ranging between 1.88-5.39 ppm for $\mathrm{SO}_{2}$ exceeded $0.5 \mathrm{ppm}$ averaged over three hours, not to be exceeded more than once per year set by US Environmental Protection Agency [EPA, 2014]. NOx are produced from the reaction of nitrogen and oxygen gases in the air during combustion, especially at high temperatures. $\mathrm{NO}_{2}$ forms quickly from emissions from cars, trucks and buses, and off-road equipments. It reacts with ammonia, moisture, and other compounds to form nitric acid vapour and related particles [EPA, 2014]. Primary $\mathrm{NO}_{2}$ emissions are particularly important from diesel vehicles (especially when moving slowly), and can make up as much as $25 \%$ of the total $\mathrm{NO}_{\mathrm{x}}$ emissions from this source. Small particles can penetrate deeply into sensitive lung tissue and damage it, causing premature death in extreme cases. Inhalation of such particles may cause or worsen respiratory diseases, such as emphysema or bronchitis, or may also aggravate existing heart disease [EPA, 2014]. In 2010, EPA revised the primary $\mathrm{SO}_{2}$ standard by establishing a new 1-hour standard at a level of 75 ppb $(0.075 \mathrm{ppm})$ which was lower than the average of $139.07 \mathrm{ppb}$ observed in this study. Nitrogen oxides and sulphur dioxide have been shown to have association with immune system impairment, exacerbation of asthma and chronic respiratory diseases, reduced lung function and cardiovascular disease [Osuntogun and Koku, 2007; Abam and Unachukwu, 2009].

\section{Air pollutant mapping}

The kriging model within the ArcGIS spatial analysis module (Version 10.0) was used to interpolate the air pollutants mapping. It was used to interpolate the different pollutant concentration to a spatial air mapping. The kriging method of interpolation is the preferred geo-statistical technique in air pollution modelling [Jerrett et al., 2005]. The spatial air pollutants mapping clearly a marked dispersion of pollutants 
in the study area (Figures 3-6). Concentration of air pollutants such as $\mathrm{CO}$ is higher around Sagamu/ Ore Expressway, Oke-Aje Market, Stadium/Oke Aje Junction, New Market Park and Oke-Owa/Ikoto/Ilese road which always have high concentration of traffic. Mean concentration of nitrogen oxide (NO) was almost uniform in all locations in the study area (Figure 4) ranging from 67-302 ppb. The spatial patterns of ambient concentrations of pollutants (Figure 3) shows highest concentration of CO around the southeastern part of the metropolis which is noted for high concentration of luxurious buses, trailers and tankers that uses diesel as fuel. The vehicles are often plying the roads or parked along the highways releasing lots of $\mathrm{CO}$ from their exhaust pipes. High concentration of $\mathrm{NO}$, $\mathrm{NO}_{2}$ and $\mathrm{SO}_{2}$ were along found around these specific areas and can be attributed to high volume of traffic.

Table 2. Concentration of Pollutants Within Selected Areas in The City

\begin{tabular}{|c|c|c|c|c|c|c|c|}
\hline Location & Abbrevation & Latitude & Longitude & NO & $\mathrm{NO}_{2}$ & $\mathrm{SO}_{2}$ & $\mathrm{CO}$ \\
\hline $\begin{array}{l}\text { Abasi Olisa/Central Mosque } \\
\text { Junction }\end{array}$ & ACJ & 6.81766 & 3.916136 & 100 & 123 & 156 & 5.7 \\
\hline Adeola Odutola/Water Junction & AWJ & 6.824951 & 3.907805 & 97 & 130 & 202 & 9.2 \\
\hline AGGS/Police Station Junction & APJ & 6.832251 & 3.90569 & 76 & 100 & 67 & 7.3 \\
\hline Alapo/Fidipote Junction & AFJ & 6.822862 & 3.912175 & 234 & 421 & 234 & 9.02 \\
\hline Awokoya/Bonojo Junction & $\mathrm{ABJ}$ & 6.831854 & 3.924758 & 109 & 120 & 231 & 8.23 \\
\hline $\begin{array}{l}\text { Balogun Kuku_Oke Aje Junc- } \\
\text { tion }\end{array}$ & $\mathrm{BKO}$ & 6.814568 & 3.929744 & 124 & 203 & 110 & 9.1 \\
\hline Bonojo/Lekuti Junction & BLJ & 6.824464 & 3.924756 & 143 & 212 & 87 & 5.3 \\
\hline Classic Hotel Roundabout & $\mathrm{CHR}$ & 6.851995 & 3.935237 & 99 & 170 & 202 & 6.2 \\
\hline Degun/Molipa Junction & DMJ & 6.828811 & 3.916506 & 99 & 150 & 189 & 10.5 \\
\hline Epe Garage Roundabout & EGR & 6.812152 & 3.930823 & 201 & 506 & 202 & 11.2 \\
\hline Erinlu/Molipa Roundabout & EMR & 6.839881 & 3.902179 & 67 & 100 & 219 & 4.8 \\
\hline FCMB/Imepe Junction & FIJ & 6.812367 & 3.912684 & 221 & 455 & 220 & 5.2 \\
\hline $\begin{array}{l}\text { Folagbade/New Road Round- } \\
\text { about }\end{array}$ & FNR & 6.824951 & 3.919002 & 187 & 300 & 176 & 6.8 \\
\hline High Court/Prison Junction & HPJ & 6.821417 & 3.928478 & 132 & 230 & 90 & 8.2 \\
\hline Ibadan Garage & IBG & 6.834461 & 3.921871 & 170 & 300 & 210 & 10.9 \\
\hline Lagos Garage Roundabout & LGR & 6.810567 & 3.910477 & 298 & 606 & 245 & 11.8 \\
\hline New Market Park & NMP & 6.816219 & 3.91312 & 212 & 346 & 145 & 12.3 \\
\hline Obalende Garage & OBG & 6.83115 & 3.906206 & 200 & 304 & 123 & 11.02 \\
\hline Ogbogbo/Igbeba Road Junction & OIJ & 6.846302 & 3.946556 & 106 & 107 & 101 & 10.1 \\
\hline Oke-Aje Market & OAM & 6.82022 & 3.930709 & 208 & 372 & 92 & 12.7 \\
\hline Oke-owa/Ikoto.Ilese & OII & 6.806006 & 3.939301 & 172 & 209 & 79 & 10.5 \\
\hline Osinubi/Bonojo Roundabout & OBR & 6.822482 & 3.924966 & 149 & 256 & 38 & 9.02 \\
\hline Ososa Junction & EOJ & 6.805987 & 3.875384 & 227 & 458 & 88 & 12.8 \\
\hline Oyingbo/Olisa Juction & OOJ & 6.815758 & 3.915332 & 208 & 442 & 102 & 10.6 \\
\hline Post Office/Ita-Ale Roundabout & PIR & 6.819568 & 3.916918 & 99 & 278 & 44 & 9.12 \\
\hline Sabo Junction & SAJ & 6.818163 & 3.90629 & 238 & 508 & 101 & 11.2 \\
\hline $\begin{array}{l}\text { Sagamu_Ore_Expressway } \\
\text { Junction }\end{array}$ & SOE & 6.791604 & 3.943007 & 302 & 662 & 230 & 13.7 \\
\hline Stadium/Oke Aje Junction & OMR & 6.818703 & 3.933694 & 202 & 322 & 78 & 9.7 \\
\hline State Hospital Roundabout & SHR & 6.813942 & 3.925609 & 107 & 296 & 66 & 8.34 \\
\hline Taused/Igbeba Junction & TIJ & 6.829573 & 3.933988 & 200 & 308 & 45 & 9.6 \\
\hline MAX & & & & 302 & 662 & 245 & 13.7 \\
\hline MIN & & & & 67 & 100 & 38 & 4.8 \\
\hline AVG & & & & 166.23 & 299.8 & 139.07 & 9.34 \\
\hline
\end{tabular}




\section{Air quality index (AQI)}

The air quality index (AQI) rating for three principal air pollutants in selected parts of the study area are tabulated in Table 3. The table also showed the AQI categories of each of the pollutants. $\mathrm{NO}_{2}, \mathrm{SO}_{2}$ and $\mathrm{CO}$ are major air pollutants in the study area as their concentration levels mostly falls within the AQI categories that is unhealthy for sensitive groups and generally unhealthy to all categories of people in the area. For this study, the monitoring process took place during the rush hour when vehicular traffic is expected to increase due to increased traffic density. Most of the areas shown in the table are road intersections, roundabout and areas of concentration of traffic where large volume of traffic including motor vehicles, tricycles, motorcycles, trailers and various truck crowd every day. Pollution in the area is aggravated by the incessant and intractable traffic congestion especially during the early hour between 7.00 a.m. to 10.00 a.m. in the morning and between 3.00 p.m. and 5.00 p.m. in the evening.

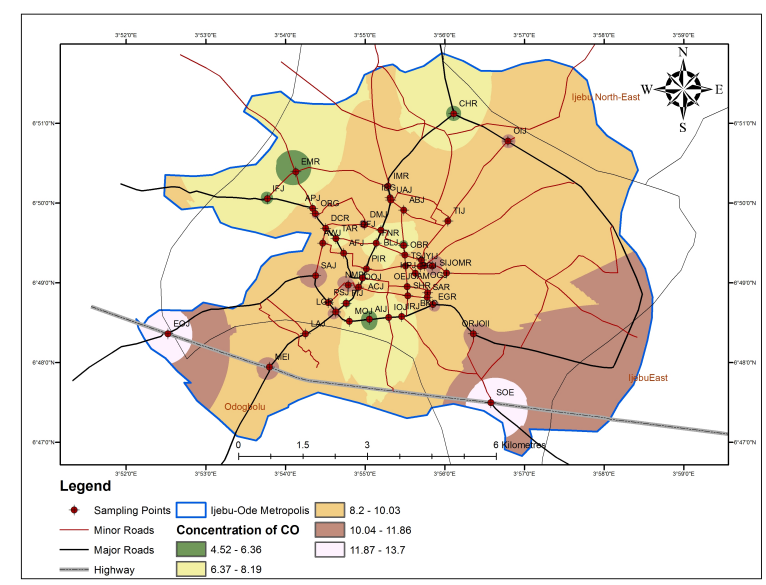

Figure 3. Concentration of CO along major roads in Ijebu-ode.

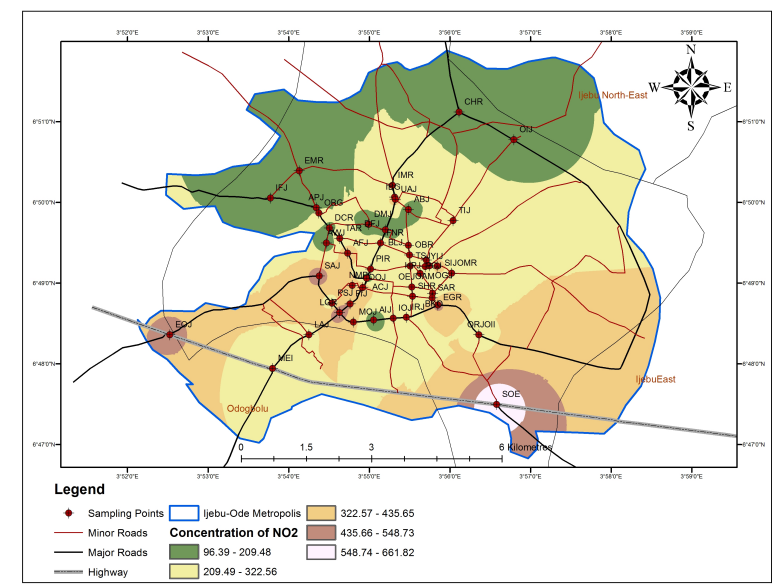

Figure 5. Concentration of $\mathrm{NO}_{\mathrm{x}}$ along major roads in Ijebu-ode.
Many of the vehicles plying the roads are not in good condition of services thus emitting huge volume of poisonous gases into the atmosphere. The air quality in these areas continue to worsen due to increase in the number of motorcycles popularly called Okada used as informal means of commercial transportation within the city. The motorcycles that are banned in some other countries because of their level of pollution are far more than taxis in number in the city. High emissions from vehicles are caused by leaking valve shafts and loose piston rings that lead to a leaking of oil into the combustion chambers of the engines. The uncombust oil releases blue plumes, bad odour and unburnt hydrocarbons. This indicate the fact that vehicular emission in typical mega cities constitutes $60 \%$ of total pollutant emission compared to industry, power plant, etc. [Abam and Unachukwu, 2009]. In terms of AQI, the results of this indicate very unhealthy air quality in the street of the study area especially at road intersection, roundabout, market areas and motor parks that usually have high concentration of humans.

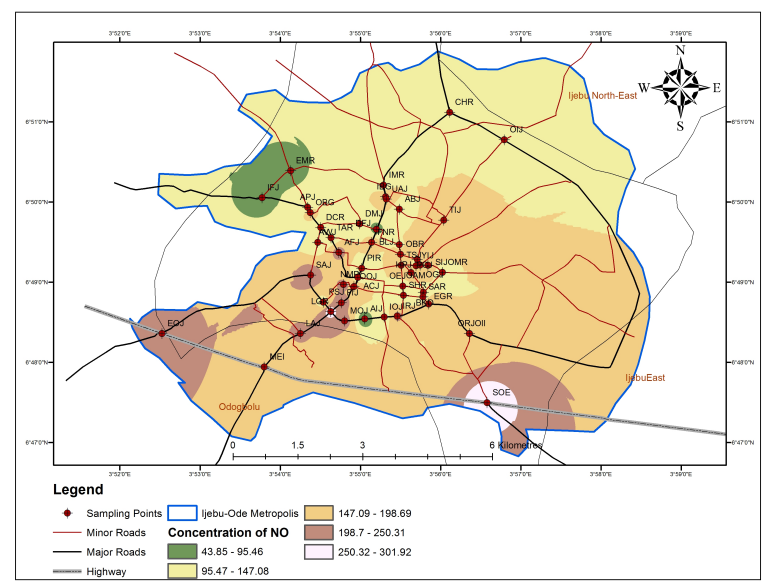

Figure 4. Concentration of $\mathrm{NO}_{2}$ along major roads in Ijebu-ode.

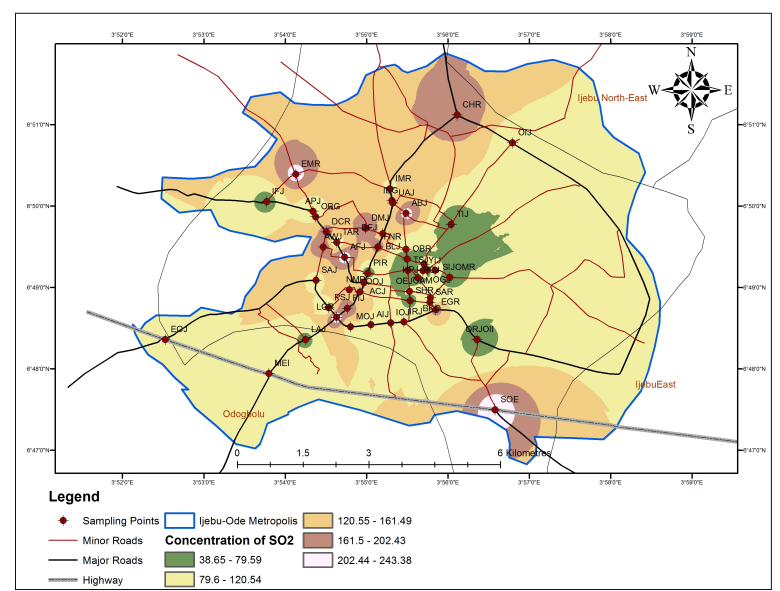

Figure 6. Concentration of $\mathrm{SO}_{2}$ along major roads in Ijebu-ode. 
This will pose significant human risk due to exposure to air pollution in urban microenvironment. Annual mean concentrations of $\mathrm{NO}_{2}$ in urban areas are generally in the range of $10-45 \mathrm{ppb}(20-90 \mu \mathrm{gm}-3)$, which vary significantly throughout the day, with peaks generally occurring twice daily as a consequence of "rush hour" traffic. Figure 7 shows the percentage contribution of each of the pollutants to air pollution in selected sampling stations. $\mathrm{NO}$ and $\mathrm{NO}_{2}$ together contributed more than $60 \%$ of the pollutant inn majority of the area studied. Table 4 shows the correlation among the different pollutants and traffic volume. It indicated positive correlation between the pollutants and traffic volume showing that the pollutants are primarily from traffic related emissions.
Table 4. Pearson Correlation of Selected Pollutants and Traffic Volume

\begin{tabular}{lrrrrr}
\hline & $\begin{array}{c}\text { Traffic } \\
\text { Volume }\end{array}$ & NO & NO2 & SO2 & CO \\
\hline $\begin{array}{l}\text { Traffic } \\
\text { Volume }\end{array}$ & 1 & & & & \\
NO & 0.613 & 1 & & & \\
NO2 & 0.513 & 0.924 & 1 & & \\
SO2 & 0.14 & 0.221 & 0.38 & 1 & \\
CO & 0.534 & 0.605 & 0.525 & -0.162 & 1 \\
\hline
\end{tabular}

\section{Conclusion}

Results from this study show that air quality in the study area is on the increase as a result of trafficrelated pollution. Many residents are exposed to dangerous levels of air pollution by pollutants such as $\mathrm{CO}, \mathrm{NO}, \mathrm{NO}_{2}$ and $\mathrm{SO}_{2}$ which may affect their health significantly. Knowledge of the interactions among these gases is crucial to understanding their

Table 3. Concentration of Pollutants Within Selected Areas in The City

\begin{tabular}{|c|c|c|c|c|c|c|c|c|c|}
\hline \multirow[t]{2}{*}{ Location } & \multicolumn{3}{|c|}{$\mathrm{NO}_{2}(\mathrm{ppb})$} & \multicolumn{3}{|c|}{$\mathrm{SO}_{2}(\mathrm{ppb})$} & \multicolumn{3}{|c|}{$\mathrm{CO}(\mathrm{ppm})$} \\
\hline & Conc. & AQI & AQI category & Conc. & AQI & AQI category & Conc. & AQI & AQI category \\
\hline AFJ & 421 & 161 & Unhealthy & 234 & 171 & Unhealthy & 9.02 & 96 & Moderate \\
\hline BKO & 203 & 120 & $\begin{array}{l}\text { Unhealthy for Sen- } \\
\text { sitive Groups }\end{array}$ & 110 & 116 & Unhealthy & 9.1 & 97 & Moderate \\
\hline EGR & 506 & 176 & Unhealthy & 202 & 158 & Unhealthy & 11.2 & 130 & $\begin{array}{l}\text { Unhealthy for } \\
\text { Sensitive Groups }\end{array}$ \\
\hline EMR & 100 & 100 & Moderate & 219 & 165 & Unhealthy & 4.8 & 54 & Moderate \\
\hline FIJ & 455 & 165 & Unhealthy & 220 & 165 & Unhealthy & 5.2 & 58 & Moderate \\
\hline IBG & 301 & 139 & $\begin{array}{l}\text { Unhealthy for Sen- } \\
\text { sitive Groups }\end{array}$ & 210 & 161 & Unhealthy & 10.9 & 125 & $\begin{array}{l}\text { Unhealthy for } \\
\text { Sensitive Groups }\end{array}$ \\
\hline LGR & 606 & 193 & Unhealthy & 245 & 176 & Unhealthy & 11.8 & 140 & $\begin{array}{l}\text { Unhealthy for } \\
\text { Sensitive Groups }\end{array}$ \\
\hline NMP & 346 & 147 & $\begin{array}{l}\text { Unhealthy for Sen- } \\
\text { sitive Groups }\end{array}$ & 145 & 132 & $\begin{array}{l}\text { Unhealthy for } \\
\text { Sensitive Groups }\end{array}$ & 12.3 & 148 & $\begin{array}{l}\text { Unhealthy for } \\
\text { Sensitive Groups }\end{array}$ \\
\hline OAM & 372 & 153 & Unhealthy & 92 & 108 & $\begin{array}{l}\text { Unhealthy for } \\
\text { Sensitive Groups }\end{array}$ & 12.7 & 154 & Unhealthy \\
\hline OII & 209 & 121 & $\begin{array}{l}\text { Unhealthy for Sen- } \\
\text { sitive Groups }\end{array}$ & 79 & 102 & $\begin{array}{l}\text { Unhealthy for } \\
\text { Sensitive Groups }\end{array}$ & 10.5 & 118 & $\begin{array}{l}\text { Unhealthy for } \\
\text { Sensitive Groups }\end{array}$ \\
\hline OOJ & 442 & 165 & Unhealthy & 102 & 113 & $\begin{array}{l}\text { Unhealthy for } \\
\text { Sensitive Groups }\end{array}$ & 10.6 & 120 & $\begin{array}{l}\text { Unhealthy for } \\
\text { Sensitive Groups }\end{array}$ \\
\hline SAJ & 508 & 176 & Unhealthy & 101 & 112 & $\begin{array}{l}\text { Unhealthy for } \\
\text { Sensitive Groups }\end{array}$ & 11.2 & 130 & $\begin{array}{l}\text { Unhealthy for } \\
\text { Sensitive Groups }\end{array}$ \\
\hline SOE & 662 & 203 & Unhealthy & 230 & 169 & Unhealthy & 13.7 & 171 & Unhealthy \\
\hline OMR & 322 & 143 & $\begin{array}{l}\text { Unhealthy for Sen- } \\
\text { sitive Groups }\end{array}$ & 78 & 102 & $\begin{array}{l}\text { Unhealthy for } \\
\text { Sensitive Groups }\end{array}$ & 9.7 & 104 & $\begin{array}{l}\text { Unhealthy for } \\
\text { Sensitive Groups }\end{array}$ \\
\hline TIJ & 308 & 140 & $\begin{array}{l}\text { Unhealthy for Sen- } \\
\text { sitive Groups }\end{array}$ & 45 & 62 & Moderate & 9.6 & 103 & $\begin{array}{l}\text { Unhealthy for } \\
\text { Sensitive Groups }\end{array}$ \\
\hline
\end{tabular}


atmospheric concentrations and lifetimes and the environmental impacts that can be expected with modifications to their sources and sinks. In order to address the problems of traffic-related air pollution in the study area, there should be establishment of a national fuel quality standard to be supported by tighter vehicle emission standards. Concerted efforts should be made towards developing and promoting alternative fuels and encouraging the use of non-motorized forms of transportation within cities. In countries like Nigeria, there is the need to establish and strengthen the healthbased standard for air pollutants. The new standard will protect public health, including the health of sensitive populations such as people with asthma, children and the elderly.

\section{References}

Abam, F.I. \& Unachukwu, G.O. (2009). Vehicular emission and air quality standards in Nigeria. European Journal of Scientific Research. 1(4), 550560.

Allegrini, I. \& Costabile, F., (2002). A new approach for monitoring atmospheric pollution in urban environment. Global Conference Building a Sustainable World. San-Paolo.

Al-Awadhi, J.M. (2014), Measurement of Air pollution in Kuwait City Using Passive Samplers. Atmospheric and Climate Sciences, 4,253-271. http://dx.doi.org/10.4236/acs.2014.42028.

Banja, M., Como, E., Murtaj, B. \& Zotaj, A. (2010). Mapping Air Pollution in Urban Tirana Area Using GIS. International Conference SDI 2010 - Skopje; 15-17.09.2010.

Baumbach, G., Vogt, U., Hein, K.R.G., Oluwole, A.F., Ogunsola, O.J., Olaniyi, H.B. \& Akeredolu, F.A. (1995). Air pollution in a large tropical city with a high traffic density-results of measurement in Lagos, Nigeria. The Science of the Total Environment. 169(1-3), 25-31.

Begum, B.A., Kim, E., Biswas, S.K. \& Hoopke, P. K. (2004). Investigation of Sources of Atmospheric Aerosol at Urban and Semi Urban Areas in Bangladesh. Atmospheric Environment. 38(1), 3025-3038.

Bellander, T., Berglind, N., Gustavsson, P., Jonson, T., Nyberg, F., Pershagen, G. \& Järup, L.(2001). Using Geographic Information Systems To Assess Individual Historical Exposure to Air Pollution from Traffic and House Heating in Stockholm. Environ Health Perspect., 109,633-639. Available Online at http://ehpnet1.niehs.nih.gov/ docs/2001/109p633-639bellander/abstract.html [Accessed 17 July 2014].

Bortnick, S.M., Coutant, B.W., \& Eberly, S.I. (2002), Using continuous PM2.5 monitoring data to report an air quality index. Journal of Air Waste Management Association. 52(1), 104-112.
Brezzi, M. \& Sanchez-Serra, D. (2014). Breathing the Same Air? Measuring Air Pollution in Cities and Regions. OECD Regional Development Working Papers, 2014/11, OECD Publishing. http://dx.doi. org/10.1787/5jxrb7rkxf21-en.

Briggs, D. (2005). The Role of GIS: Coping With Space (And Time) in Air Pollution Exposure Assessment. Journal of Toxicology and Environmental Health.68(13-14), 1243-61.

Chattopadhyay, S., Gupta, S. \& Saha, R.N. (2010). Spatial and Temporal Variation of Urban Air Quality: A GIS Approach. Journal of Environmental Protection. 1(Sept), 264-277.

Clougherty, J.E., Wright, R.J., Baxter, L.K. \& Levy, J.I. (2008). Land use regression modeling of intraurban residential variability in multiple trafficrelated air pollutants. Environ Health. 7(17), 1-14.

Cheng, W., Chen, Y., Zhang, J., Lyons, T.J., Pai, J., \& Chang, S., (2007). Comparison of revised air quality index with the PSI and AQI indices. Science of the Total Environment. 382(2-3), 191-198.

Council of Ministers Responsible for Transportation and Highway Safety (CMRTHS) (2013). Canada's National Highway System Annual Report 2012. Ottawa. Ontario. 43 pp. http://www.comt.ca/ english/NHS\%20Annual\%202012.pdf [Accessed 17 July 2014].

Cohen A.J. et al. (2004). Urban Air Pollution. Chapter 17 in Comparative Quantification of Health RisksGlobal and Regional Burden of Disease Attribution to Selected Major Risk Factors. The World Health Organization, available at: http://www.who. int/publications/cra/chapters/volume2/1353-1434. pdf.

Cohen, A.J., Anderson, H.R., Ostra, B., DevPandey, K., Krzyzanowski, M., Kunzli, N., Guschmidt, K., Pope, A., Romieu, I.,Samet, J.M. \& Smith, K. (2005). The Global Burden of Disease due to Outdoor Air Pollution. Journal of Toxicology and Environmental Health. 68(13-14), 1301-1307.

Council of Ministers Responsible for Transportation and Highway Safety (CMRTHS) (2013). Canada's National Highway System Annual Report 2012. Ottawa, Ontario. 43 pp. http://www.comt.ca/ english/NHS\%20Annual\%202012.pdf [Accessed 17 July 2014].

Dons, E., Van Poppel, M., Kochan, B. \& Wets, G. (2013). Int $P$ anis L. Modeling temporal and spatial variability of traffic-related air pollution: hourly land use regression models for black carbon. Atmos. Environ. 74(augst), 237-246.

Dubey, B. (2014). Application of air pollution models and remote sensing in Air Quality Management. Indian Journal of Applied Research. 4(5), 266-268.

Dyominov, I.G. \& Zadorozhny, A.M. (2005). Greenhouse gases and recovery of the Earth's ozone layer. Advances in Space Research. 35(8), 1369-1374. Enkhtur, B. (2013). Geostatistical Modelling and 
Mapping of Air Pollution. MSc. Thesis. Faculty of Geo-Information Science and Earth Observation. University of Twente. Enschede. the Netherlands.

EPA (2006). Guideline for Reporting of Daily Air Quality - Air Quality Index (AQI). EPA-454/B-06-001 May 2006.

EPA (2014). Fact Sheet - Air Quality Designations for the 2010 Primary Nitrogen Dioxide (NO2) National. Ambient Air Quality Standards.

ESRI. (2007). GIS for Air Quality. Available at: http:// www.esri.com/library/bestpractices/air-quality.pdf [Accessed 17 July 2014].

Ettouney, R.S., Abdul-Wahab, S.A. \& Elkilani, A.S. (2009). Emissions Inventory, ISCST, and Neural Network Modelling of Air Pollution in Kuwait. International Journal of Environmental Studies. 66(2), 193-206.

Gulliver, J. \& Briggs, D. (2011). STEMS-Air: A simple GIS-based air pollution dispersion model for citywide exposure assessment. Science of the Total Environment. 409(12), 2419-2429.

Gupta, P., Christopher, S.A., Wang, J., Gehrig, R., Lee, Y. \& Kumar, N. (2006). Satellite remote sensing of particulate matter and air quality assessment over global cities. Atmospheric Environment. 40(30), 5880-5892.

Hadjimitsis, D.G., Nisantzi, A., Themistocleous, K., Matsas, A., \& Trigkas, V. P. (2010). Satellite remote sensing, GIS and sun-photometers for monitoring PM10 in Cyprus: issues on public health, Proc. SPIE 7826, 78262C (2010); doi:10.1117/12.865120.

Hadjimitsis, D.G. Themistocleous, K. \& Nisantzi, A. (2012). Air Pollution Monitoring Using Earth Observation \& GIS, Chapter 5. 117-140. In: Dr. Mukesh Khare (Ed.), Air Pollution - Monitoring, Modelling and Health. ISBN: 978-953-510424-7. InTech, Available from: http://www. intechopen.com/books/air-pollution-monitoringmodellingand-health/air-pollution-monitoringusing-earth-observation-gis.

Jain, M., Saxena, A., Saxena, P.K. \& Singh, P. (2008). A Decision Support System for Health E ffe ct s due to Transportation Pollution. Proceedings of the Conference on Cooperation for Urban Mobility in Developing World (CODATUXIII). Ho Chi Minh City. Vietnam. 2008 Tuesday 11th November, 2008-Friday 14th November. 2008 at Ho Chi Minh City. Vietnam 10 pages. C. Piccard, J, llaire, L., Tomason, and A. Trione (Eds.). CD_ROM.

Laumbach, R.J. \& Kipen, H.M.. (2012). Respiratory health effects of air pollution: update on biomass smoke and traffic pollution. J Allergy Clin Immunol.29(1), 3-11.

Matejicek, L., (2005). Spatial Modelling of Air Pollution in Urban Areas with GIS: A Case Study on Integrated Database Development. Advances in Geosciences. 4(2005), 63-68.

Murena, F., (2004). Measuring air quality over large urban areas: Development and application of an air pollution index at the urban area of Naples. Atmospheric Environment. 38(2004), 6195-6202.

Mwenda, L.P. (2011). Geostatistical analysis of air pollution using models, in situ and remote sensed data. MSc Thesis. University of Twente, Faculty of Geo-Information and earth Observation. ITC. Enschede.

National Population Commission (NPC) (2006). Final Results of the 2006 Census. Abuja: National Population Commission.

Odindi, J, Mhangara, P \& Kakembo, V. (2012). Remote sensing land-cover change in Port Elizabeth during South Africa's democratic transition. South African Journal of Science. 108 (5/6), 1- 7.

Olajire, A.A., Azeez, L. \& Oluyemi, E.A.(2011). Exposure to hazardous air pollutants along Oba Akran road, Lagos - Nigeria. Chemosphere. 84(8), 1044-1051.

Osuntogun, B.A., \& Koku, C.A., (2007). Environmental impacts of urban road transportation in SouthWestern states of Nigeria. Journal of Applied Sciences. 7 (16), 2356-2360.

Ozcan, H.K. (2012). Long term variations of the atmospheric air pollutants in Istanbul city. Int. J. Environ. Res. Public Health. 9(3), 781-790.

Paez, D., Thirouin, M., Orjuela, J. P. \& Perry, A. (2013). GIS Model for Air Quality Consideration in the Strategic Design and Evaluation of Bicycle Infrastructure: Case Study in Bogota 12th WCTR, July 15-18, 2013 -Rio de Janeiro. Brazil.

Rahman, S. R.A., Ismail, S.N.S., Raml, M.F., Latif, M.T., Abidin, E.Z. \& Praveena, S.M. (2015). The Assessment of Ambient Air Pollution Trend in Klang Valley. Malaysia. World Environment. 5(1), 1-11.

Rahmatizadeh, Sh., Delavar, M. R., \& Motessadi, S. (2003). Application of GIS in Air Quality Management, Proc. First national Air Pollution congress. Tehran. Iran.

Raju, H. P., Partheeban, P. \& Hemamalini, R. R. (2012). Urban Mobile Air Quality Monitoring Using GIS, GPS, Sensors and Internet. International Journal of Environmental Science and Development. 3(4), 323327.

Ramanathan, V. and Feng, Y. (2009). Air pollution, greenhouse gases and climate change: global and regional perspectives. Atmospheric Environment. 43(1), 37-50.

Revi, A., D.E. Satterthwaite, F. Aragón-Durand, J. Corfee-Morlot, R.B.R. Kiunsi, M. Pelling, D.C.Roberts, \& W. Solecki (2014). Urban areas. In: Climate Change 2014: Impacts, Adaptation, and Vulnerability. Part A: Global and Sectoral Aspects. Contribution of Working Group II to the Fifth Assessment Report of the Intergovernmental Panel on Climate Change [Field, C.B., V.R. Barros, D.J. Dokken, K.J. Mach, M.D. Mastrandrea, T.E. Bilir, M. 
Chatterjee, K.L. Ebi, Y.O. Estrada, R.C. Genova, B. Girma, E.S. Kissel, A.N. Levy, S. MacCracken, P.R. Mastrandrea, and L.L. White (eds.)]. Cambridge University Press, Cambridge, United Kingdom and New York, NY, USA, pp. 535-612.

Sameen, M.I., Al Kubaisy, M.A., Nahhas, F.H., Ali, A.A., Othman, N. \& Hason, M. (2014). Sulfur Dioxide (SO2) Monitoring Over Kirkuk City Using Remote Sensing Data. J Civil Environ Eng. 4(155), 1-6.

Sampson, P.D., Szpiro, A.A., Sheppard, L., Lindstrom, J. \& Kaufman, J.D. (2011). Pragmatic estimation of a spatio-temporal air quality model with irregular monitoring data. Atmospheric Environment 45 (36), 6593-6606.

Satterthwaite, D. (2007). The Transition to a Predominantly Urban World and its Underpinnings. Human Settlements Discussion Paper. IIED. London. 86 pages.

Smallbone K. (1998). Mapping ambient urban air pollution at the small area scale: a GIS approach. Unpublished PhD thesis. Department of Geography. University of Huddersfield. UK.

Touloumi, G., Atkinson, R., \& Terte, A.L., (2004). Analysis of health outcome time series data in epidemiological studies. Environmetrics 15(2), 101-117.

United Nations ESCAP (Economic and Social Commission for Asia and the Pacific) (2013). Statistical Yearbook for Asia and the Pacific Available online at: http://www.unescap.org/stat/ data/syb2013/H.2-Transport.asp [Accessed 17 July 2014].

USEPA (2009). Integrated Science Assessment for Particulate Matter. Available at: http://www.epa. gov/ncea/pdfs/partmatt/Dec2009/PM_ISA_full. pdf.

van der Kassteele, J., Stein, A. \& Dekkers, A.L.M. (2006). Statistical air quality mapping. PhD Thesis. Wagenigen Universiret. Wagennigen.

Watmough, S.A., McDonough, A.M. \& Raney, S.M. (2014). Characterizing the influence of highways on springtime $\mathrm{NO} 2$ and $\mathrm{NH} 3$ concentrations in regional forest monitoring plots. Environmental Pollution. 190(july), 150-158.

World Health Organisation/United Nation Environment Programme (WHO/UNEP) (1992). Urban air pollution in megacities of the world.

WHO (2011). Air quality and health. Available at: http://www.who.int/mediacentre/factsheets/fs313/ en/ [Accessed 22 December 2014].

World Bank (2003), World Development Indicators. World Bank Publications, Washington DC.

Wu, P. (2006). Modeling Transportation Related Emissions Using GIS. Transportation Technology and Policy Graduate Group. Institute of Transportation Studies, the University of California. Davis. November 2006.

Xia, L. \& Shao, Y. (2005). Modelling of traffic flow and air pollution emission with application to Hong Kong Island. Environmental Modelling \& Software 20(9), 1175-1188.

Zhu Y, Hinds WC, Kim S, \& Sioutas C. (2002), Concentration and size distribution of ultrafine particles near a major highway. J Air Waste Manag Assoc. 52(9), 1032-1042. 